\title{
Rebirth of childbirth: reflections on medicalization of the Brazilian obstetric care
}

\author{
Renascimento do parto: reflexões sobre a medicalização da atenção obstétrica no Brasil \\ Renacimiento del parto: reflexiones sobre la medicalización de la atención obstétrica en Brasil
}

\section{Samara Calixto Gomes', Lívia Parente Pinheiro Teodoro', Antonio Germane Alves Pinto', Dayanne Rakelly de Oliveira', Glauberto da Silva Quirino', Ana Karina Bezerra Pinheiro"}

' Universidade Regional do Cariri. Crato, Ceará, Brazil.

"Universidade Federal do Ceará. Fortaleza, Ceará, Brazil.

How to cite this article:

Gomes SC, Teodoro LPP, Pinto AGA, Oliveira DR, Quirino GS, Pinheiro AKB. Rebirth of childbirth: reflections on medicalization of the Brazilian obstetric care Rev Bras Enferm [Internet]. 2018;71(5):2594-8. DOI: http://dx.doi.org/10.1590/0034-7167-2017-0564

Submission: 09-19-2017

Approval: 01-09-2018

\section{ABSTRACT}

Objective: to reflect on the medicalization process of childbirth and birth and its consequences based on a Brazilian audiovisual media artifact. Method: reflective and interpretive analysis of the documentary O Renascimento do Parto (The Rebirth of Childbirth) based on Critical Discourse Analysis. Results: c-section emerges as an alternative to adverse conditions of pregnancy. However, it has become a routine and abusive practice of a medicalized obstetric care, thus becoming a social problem. In order to the incidence of c-sections decrease, women's protagonism must be restored, in addition to considering psychological, affective, emotional, spiritual, cultural, and contextual aspects in childbirth. Conclusion: childbirth is established as a material element and a mental phenomenon of social practices. We must interrupt the predominant model, allowing the body to express itself through the release of oxytocin, and decrease the segregation that c-section causes, thus enabling affective bonds.

Descriptors: Childbirth; Natural Childbirth; Medicalization; Obstetrics; Doulas.

\section{RESUMO}

Objetivo: refletir sobre o processo de medicalização ao parto e nascimento e suas consequências, a partir de um artefato midiático audiovisual brasileiro. Método: análise reflexiva e interpretativa do documentário "O Renascimento do Parto", baseada na Análise do Discurso Crítica. Resultados: a cesariana configura-se como alternativa para condições adversas gestacionais. Entretanto, tornou-se uma prática rotineira e abusiva, de uma atenção obstétrica medicalizada, passando a ser um problema social. Para que a incidência de cesarianas diminua é necessário que seja restituído o protagonismo da mulher, além de considerar aspectos psicológicos, afetivos, emocionais, espirituais, culturais e contextuais no parto. Conclusão: o parto configura-se como elemento material e fenômeno mental das práticas sociais. É necessário romper com o modelo predominante, permitir que o corpo se expresse por meio da liberação de ocitocina e diminuir a segregação que a cesariana provoca, proporcionando a formação de vínculos afetivos.

Descritores: Parto; Parto Natural; Medicalização; Obstetrícia; Doulas.

\section{RESUMEN}

Objetivo: reflexionar sobre el proceso de medicalización al parto y nacimiento y sus consecuencias, a partir de un artefacto mediático audiovisual brasileño. Método: análisis reflexivo e interpretativo del documental "O Renascimento do Parto", basado en el Análisis Crítico del Discurso. Resultados: la cesárea se configura como alternativa a condiciones adversas en la gestación. Sin embargo, se convirtió en una práctica rutinaria y abusiva, de una atención obstétrica medicalizada, pasando a ser un problema social. Para que la incidencia de cesáreas disminuya es necesario que sea restituido el protagonismo de la mujer, además de considerar aspectos psicológicos, afectivos, emocionales, espirituales, culturales y contextuales en el parto. Conclusión: el parto se configura como elemento material y fenómeno mental de las prácticas sociales. Es necesario romper con 
el modelo predominante, permitir que el cuerpo se exprese por medio de la liberación de oxitocina y disminuir la segregación que la cesárea provoca, proporcionando la formación de vínculos afectivos.

Descriptores: Parto; Parto Normal; Medicalización; Obstetricia; Doulas.

\section{CORRESPONDING AUTHOR_Samara Calixto Gomes_E-mail: samaracalixto@hotmail.com}

\section{INTRODUCTION}

Childbirth and birth are phenomena that undergo modifications according to the society in which they are inserted. The current obstetric scenario reflects an institutionalization of practical knowledge associated with childbirth and invasive procedures, often unnecessary and potentially iatrogenic, resulting in the loss of women's autonomy ${ }^{(1-2)}$. This process is called medicalization.

The routine performance of c-sections causes the isolation of pregnant women and their families, negatively interferes in newborn care, and puts the maternal and fetal health at risks, becoming an abusive procedure and hindering the adoption of humanization conducts in this process. Women are subject to strict and mechanized routines that are adopted without critical evaluation on a case-by-case basis ${ }^{(3)}$. Therefore, the high number of c-sections can cause more harm than good to mothers and the fetuses.

Concerning the c-sections performed in the Brazilian Unified Health System (Sistema Único de Saúde - SUS), there was an increase from $38.3 \%$ in 2001 to $55.15 \%$ in $2014^{(4)}$. From such index, we infer that Brazil lives an epidemic of elective c-sections.

Hence, considering the medicalization aspects of the Brazilian obstetric care and its development, such as high rates of c-sections and the circulation of collective discourses of risk in the pregnant-puerperal cycle, we aim to reflect on the process of medicalization of childbirth and its consequences, from a Brazilian audiovisual media artifact.

The documentary O Renascimento do Parto (The Rebirth of Childbirth) portrays this period of late modernity, in which such practices result in turning women into frail and incapable parturients, believing they need aid to achieve the birth of their child, denying their own capacity to give birth and decreasing their potential ${ }^{(5)}$.

This reflection is justified because vital events, such as the birth, are based on a model centered in medical technology, favoring the emergence of a c-section culture, in which common symptoms or ordinary factors become the reason for choosing the surgical procedure. Childbirth assistance in Brazil is still characterized by procedural attitudes supported by cultural changes, and convenient interventions are imposed to knowledge and practices established by the biomedical field.

Therefore, we focus on the formation of social and discursive practices concerning this late modernity, in order to contribute to a more complex vision of births.

\section{OBJECTIVE}

To reflect on the medicalization process of childbirth and its consequences, from a Brazilian audiovisual media artifact.

\section{METHOD}

This is a reflective and interpretive analysis based on the documentary $O$ Renascimento do Parto. To this end, data are presented for the production and construction of our narrative, being analyzed its content by two analytical categories: Giving birth to life: from nature to medicalization; Between perceptions and affections: where are the love hormones? In such categories were used excerpts from interviews in the documentary that support and illustrate their central ideas.

This study analyzes discursive practices for establishing identities of the professionals and the pregnant women within the current obstetric scenario. The best way to analyze an audiovisual material is choosing a theoretical framework and applying it to the empirical object. Hence, our analysis was based on Critical Discourse Analysis (CDA). The theoretical and methodological assumptions of $\mathrm{CDA}$, formulated and presented considering the concepts of the British linguist Norman Fairclough ${ }^{(6)}$, will be useful to create this framework of statements present in the documentary.

The following step was selecting a sampling framework, which would be the medicalization of childbirth, and then creating rules for the transcription of visual and verbal information, selecting illustrative citations that would complement the visual analysis.

To do so, were considered three essential elements in discourse analysis: production, in the case of the documentary, highlighting its authors, producers, and other contributors; the text itself; and the reception regarding the interpretation by those who watch the documentary. For a production to make sense, it is not necessary for it to be within the text; it can be what "has not been said." Thus, it is possible to identify its assumptions( ${ }^{(7)}$.

The documentary is a Brazilian production that addresses, as a public accusation, the increase of c-sections in Brazil and which stands for the autonomy of women during childbirth. The movie lasts 90 minutes and it was directed by Eduardo Chauvet, screenplay by Érica de Paula, photography by Rafael Morbeck, and soundtrack by Charles Torres and Marcello Dalla. It was released in August 2013 in Brazil and features statements ranging from personal experiences to results of scientific research.

Among the interviewees, we highlight the participation of Michel Odent (French obstetrician, specialist in water birth and symbol of the natural childbirth), Robbie Davis-Floyd (lecturer, cultural anthropologist, specialist in anthropology of reproduction), Daphne Rattner (epidemiologist, with a PhD from the University of North Carolina, and professor at the University of Brasilia, executive coordinator of Rede pela Humanização do Parto e Nascimento [Network for Humanization of Childbirth and Birth]), Naoli Vinaver (Mexican doula), and the Brazilian couple Márcio Garcia (actor) and Andréa Santa Rosa (nutritionist). 
In addition, Brazilian doctors/obstetricians, pediatricians, nurses, doulas, midwives, and women with maternal experiences both positive and negative participated in the documentary. Considering the speeches, participants contributed positively reporting the historical process of transformation of this paradigm, when the birth art, for a long period, was classified as an exclusively female function.

\section{Giving birth to life: from nature to medicalization}

The categories were classified as elements, since according to CDA social life is composed of social practices in constant and unstable articulation, thus considering discourse as an element of these practices. The first category was described as element 1 , in which childbirth was chosen as an example of a material activity.

During the Middle Ages, labor was perceived as the main role of women, and religious decrees forbade the male presence within the giving birth scenario, making it an activity exclusively feminine. Initially, parturient women received empirical care from women who were considered to be witches and those who were curious. However, over time, this kind of behavior has been modified by man. The male figure appears in the history of childbirth by introducing obstetrics as a science, implementing the horizontal delivery and episiotomy ${ }^{(2)}$.

From the consolidation of hospital delivery, the medicalization of this event resulted in the loss of women's autonomy as bellwether of the giving-birth process, leaving this physiological and vital event to be marked by the overuse of invasive practices, often unnecessary and potentially iatrogenic ${ }^{(5)}$. These conditions ended up resulting in oppression situations, whether due to the medicalization of the female body or the non-recognition of women's protagonism in this process. "We can't give birth the way our mothers and grandmothers did. We can't do what once was considered normal!". (Mariana Carvalho, mother and public administrator) ${ }^{(8)}$.

In such speech, the interviewee begins her report in the present tense, promoting the idea of women's inability to act when giving birth, especially when stating "we can't do what once was considered normal." This idea, along with the phrase "We can't give birth the way our mothers and grandmothers did," illustrates the order of discourse of change in the obstetric reality and women's appropriation in their own labor.

The transfer of the birth environment improved health indicators in Brazil, especially concerning the reduction of maternal and neonatal mortality rates over the past thirty years ${ }^{(9)}$. In ideal conditions, the c-section is safe and contributes to reducing maternal and perinatal morbidity and mortality, hence its value in modern obstetrics. However, the negative consequence was the increase in the number of interventions at birth without justified medical reasons. In this sense, the World Health Organization states that rates above the range of 10 to $15 \%$ do not contribute to reducing maternal, perinatal, or neonatal mortality. In the Brazilian context, in which there is a high rate of already-performed c-sections, the reference rate is estimated around $29 \%{ }^{(10)}$.

It is noteworthy that the counterproductive feature induced by the elective c-section, understood as the imbalance between autonomous health actions, such as products of the interaction of the individual with the social environment, and heteronomous health actions, undertake by health professionals and specialists within the institutionalization context, results in an illusion of needing more heteronomous actions for correcting undesirable and potentially harmful consequences, transforming this reality in a vicious circle. "Women ended up conforming to strict standards established by the medical system according to which they must give birth in a given time and behave in a certain way". (Ricardo Jones, obstetrician) ${ }^{(8)}$.

In the second speech, the doctor describes the female resilience, mentioning the conformation and consequent adaptation of women to medicalized acts, without expecting a justification for such action. At the same time, in his speech the doctor blames the public system, when stating that women "must give birth in a given time and behave in a certain way."

Standardization of the labor process is a structural condition of late modernity, which equals people and situations in conditions of economic, social, and cultural inequality. Therefore, a consumption need is produced, conditioned by professional interests that culminate in an identification on the part of some women.

C-section ends up being the result of a cultural and social medicalization. In this sense, the public system itself, the reality of the health situation in our country, and the obstetric care model contribute to such results.

\begin{abstract}
"There is a cultural logic on top of that. [...] The patient has the idea that the c-section is more controlled, less risky, or with no risk at all. And that her baby will be safe. The doctor, on the other hand, despite having learned that natural childbirth is safe, that is good for the baby, ends up believing in the false fact that c-section is safer". (Fernanda Macedo,

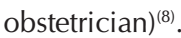

The expectation of a "safe delivery" is associated with the "tranquility" of a c-section. The doctor describes such attitude when stating that women believe "c-section is more controlled, less risky, or with no risk at all." Thus, the last two statements may be representative of the power of medicine and the feeling of non-participation of women in an act that once was natural.

The idea of greater control in the c-section is established by elements of the surgical technique which require greater knowledge and professional skill, instituting a power-knowledge path. In addition, there is the possibility of controlling variables, such as time, which allows increasing productivity. However, the little time directed to women's care may negatively reverberate to the establishment of the professional-patient bond. Such bond is surrounded by affections, and these may generate comfort and delight.

In a counter-hegemonic way, professionals working in obstetric care, especially doctors and nurses who are interest in restoring the vaginal delivery, work with evidence-based health practices, in order to reduce the trivialization of this type of procedure. However, it is still a paradigm to be overcome and a challenge, since medicalization has been established by diverse strategies, using different actors, including the state mediation. The result was the exclusion of women from their traditional practices, an issue that is discussed by the movement of humanization of labor and birth. 
Between perceptions and affections: where are the love hormones?

The second category represents the mental phenomena. Overall, they concern feelings, beliefs, and values. For this reason, the hormonal cocktail produced by women during labor was chosen to represent the element 2.

During labor, women are physiologically prepared for the upcoming release of hormones that are programmed to act before, during, and after the child's birth and that influence the behavior and bond between mother and son, which may have an impact even on the ability to love and on people's potential aggression.

Unnecessary c-section prevents the production of the hormonal cocktail, which has oxytocin as the main secreted substance. During labor, such hormone triggers contractions that precede it, performing many functions that are beneficial for both the mother and the newborn. In addition, oxytocin is also produced during sexual activity, being responsible for male and female orgasms, and when breastfeeding ${ }^{(8)}$.

"Until recently, love was the theme of poets, philosophers, and novelists. But today, love is also studied by scientists. Nowadays we understand that the ability to love is largely organized and built during the period comprising the birth". (Michael Odent, obstetrician and researcher) ${ }^{(8)}$.

The obstetrician Michael Odent describes this hormonal production as a feeling. When he says "the ability to love is largely organized and built during the period comprising the birth," he narrates the importance of creating the bond between the binomial mother/son.

These hormones produced at childbirth will favor the development of the bond, thus avoiding possible complications and making maternal recovery faster ${ }^{(8)}$. In addition to physiological aspects, the birth organizes and builds our capacity to love; the labor period has potential for achieving this goal, as well as it allows developing the female body awareness and relationships with the people that are meaningful, which reflects on the strengthening of affective bonds.

"Labor is not only a physiological act that begins with contractions and ends with pushing the baby and the placenta out. It is, above all, a true rite of initiation, of passage, not only for the mother, but also for the whole family and the baby that actively participates in this experience and come out of it stronger".(Érica de Paula - Doula)

"People think that giving birth is a bodily thing. [...] A physical thing only. But... over the years that I monitor labor processes, I see that it is the soul of the woman expressing itself through the body". (Naoli Vinaver - Doula) ${ }^{(8)}$.

Some doulas also participated in the documentary, and their speeches express the subjective side of childbirth. One of them evidenced this when saying that giving birth is "above all, a true rite of initiation, of passage," making it clear that the experience of this moment makes women more assured of their emotional capacity. The giving-birth process provides women the transcendence of boundaries, connecting them with their inner I to the extent it promotes the expression of their soul through the body.
Labor as a rite of initiation is based on the premise that, with it, a mother, a child, a father, and a family are born - an event that establishes a multiple-implication relationship that, when positively experienced, is able to generate happiness and to strengthen the affective and social relations.

C-section radically separates the newborn, the placenta, and the mother from each other. The coldness situation worsens with the absence of love hormones. Elective c-sections prevent the labor process and, consequently, the action of hormones essential for childbirth and for strengthening the creation of the bond between mother and son.

To the profile of the c-section incidence decreases, some aspects are required: to restore the protagonism of women at the labor process; integrative and comprehensive vision of the phenomenon, involving psychological, affective, emotional, spiritual, cultural, and contextual aspects in which the labor takes place ${ }^{(1)}$.

Updating our way of thinking with new theories of thought will provide a new worldview, in which the separation would be replaced by the interrelationship and integration of all physical, biological, psychological, social, political, and cultural phenomena $^{(8)}$.

We should raise awareness about the cultural process in which we are inserted, process which has the potential to produce a broader thinking, able to fulfill our need to know, given our need to want and our freedom to feel, representing, therefore, the way amid this fragmented culture.

\section{Study limitations}

The scope of two thematic categories.

Contributions to the field of nursing, health, or public policy Indicating CDA as an element to understand the social phenomena that relate to medicalization of obstetric care in Brazil is essential to the professional ethos of nursing. This understanding is essential to comprehend that the role of the nurse midwife in the childbirth care decreases unnecessary interventions, which reflects on the reduction of the rates of c-sections, the increase of women's protagonism, and the respect concerning the physiological, emotional, and social dimensions within the giving birth/being born process.

\section{FINAL CONSIDERATIONS}

Childbirth is established as a material element and a mental phenomenon of social practices. Therefore, it is polysemic and subject to interventions, especially when health is guided by a hegemonic biomedical model, which produces medicalization of vital events.

This process has as consequences the increase of medical intervention in labor and birth, which in Brazil is reflected on the increase in c-section rates beyond what is considered acceptable by international public organs and on the loss of women's autonomy. Hence, we acquired a knowledge that standardizes behaviors, disciplines bodies, and controls the physiological events that are inherent in life.

However, the body is not linear, but complex; there are physiological events which are culturally meaningful to express its 
creative potential. Oxytocin, understood as the hormone of love and delight, is produced during labor and causes pain, which is inherent in life, but which promotes and encourages the labor process and, therefore, increases the potential to generate happiness.

In order to the "rebirth" of childbirth takes place, it is necessary to interrupt this hegemonic model of obstetric care in Brazil; to allow the body, during parturition and as physiological and cultural unit, to express itself through the release of oxytocin; to decrease the segregation between mother and son that the c-section causes and restore women's autonomy, improving the creation of affective bonds between patients, the newborn, family, and healthcare professionals, making this vital event less negative and considering the complex understanding that such is part of the sexual, emotional, and social life of women.

\section{FUNDING}

Fundação Cearense de Apoio ao Desenvolvimento Científico e Tecnológico (Funcap) and National Council for Scientific and Technological Development (CNPq).

\section{REFERENCES}

1. Reis TLR, Padoin SMM, Toebe TRP, Paula CC, Quadros JS. Women's autonomy in the process of labour and childbirth: integrative literature review. Rev Gaúcha Enferm [Internet]. 2017[cited 2017 Jul 06];38(1):e64677. Available from: http://www.scielo.br/pdf/ rgenf/v38n1/en_0102-6933-rgenf-1983-144720170164677.pdf

2. Campos AS, Almeida ACCH, Santos RP. Crenças, mitos e tabus de gestantes a cerca do parto normal. Rev Enferm UFSM[Internet]. 2014[cited 2017 Jun 28];4(2):332-41. Available from: https://periodicos.ufsm.br/reufsm/article/view/10245/pdf

3. Riscado LC, Jannotti CB, Barbosa RHS. Deciding the route of delivery in Brazil: themes and trends in public health production. Texto Contexto Enferm [Internet]. 2016 [cited 2017 Jun 14];25(1):e3570014. Available from: http://www.scielo.br/pdf/tce/v25n1/ en_0104-0707-tce-25-01-3570014.pdf

4. Brasil. Ministério da Saúde. Datasus. Sistema de Informações sobre Nascidos Vivos (SINASC) [Internet]. Brasília: Ministério da Saúde; 2017[cited 2017 Nov 20]. Available from: http://tabnet.datasus.gov.br/cgi/tabcgi.exe?pacto/2015/cnv/coapcirbr.def

5. Velho MB, Santos EKA, Collaço VS. Parto normal e cesárea: representações sociais de mulheres que os vivenciaram. Rev Bras Enferm [Internet]. 2014 [cited 2017 Jun 21];67(2):282-9. Available from: http://www.scielo.br/pdf/reben/v67n2/0034-7167reben-67-02-0282.pdf

6. Costa AF, Castro LC. A noção de sujeito na abordagem discursiva de Norman Fairclough. Signótica [Internet]. 2014[cited 2017 Nov 20];26(2):437-55. Available from: https://www.revistas.ufg.br/sig/article/view/29468

7. Fairclough N. Analysing discourse: textual analysis for social research. 2nd ed. London and New York: Taylor \& Francis Group; 2004.

8. Paula E, Chauvet E. O Renascimento do parto [DVD]. Brasília: Master Brasil e Ritmo Filmes; 2013. (90 minutos).

9. Ministério da Saúde. Parto e nascimento domiciliar assistidos por parteiras tradicionais: o Programa Trabalhando com Parteiras Tradicionais e experiências exemplares[Internet]. Brasília: Ministério da Saúde; 2012[cited 2017 Jun 14]. Available from: http:// bvsms.saude.gov.br/bvs/publicacoes/parto_nascimento_domiciliar_parteiras.pdf

10. Brasil. Ministério da Saúde. Diretrizes de atenção à gestante: a operação cesariana[Internet]. Brasília: MS; 2015 [cited 2017 Nov 20]. Available from: http://conitec.gov.br/images/Consultas/Relatorios/2015/Relatorio_PCDTCesariana_CP.pdf 